\title{
Evaluasi Program Bantuan Pangan Non Tunai dalam Penanggulangan Kemiskinan di Kecamatan Nanggalo Kota Padang
}

Suci Laurentcia, Rahmadani Yusran

Jurusan Ilmu Administrasi Negara

FIS Universitas Negeri Padang

E-mail: yusranrdy@fis.unp.ac.id

\section{ABSTRAK}

Penelitian ini bertujuan menganalisis evaluasi Program Bantuan Pangan Non Tunai dalam Penanggulan Kemiskinan di Kecamatan Nanggalo Kota Padang. Bantuan Pangan Non Tunai (BPNT) merupakan salah satu bentuk program Bantuan Sosial Non Tunai (BSNT). Adapun tujuan dari BPNT menurut Peraturan Menteri Sosial Republik Indonesia Nomor 20 tahun 2019 adalah; (1) Mengurangi beban pengeluaran KPM BPNT melalui pemenuhan sebagian kebutuhan pangan; 2) memberikan bahan pangan dengan gizi seimbang kepada KPM BPNT; 3) memberikan bahan pangan dengan tepat sasaran, tepat waktu, tepat jumlah, tepat kualitas, tepat harga, dan tepat administrasi; dan 4) memberikan lebih banyak pilihan dan kendali kepada KPM BPNT dalam memenuhi kebutuhan pangan. Penelitian ini merupakan penelitian kualitatif dengan menggunakan metode deskriptif. Informan penelitian ditentukan dengan cara purposive sampling. Teknik pengumpulan data dilakukan melalui wawancara, observasi, dan studi dokumentasi serta dilakukan reduksi data agar bisa ditarik kesimpulan yang akurat dari data yang telah didapat. Hasil penelitian menunjukkan bahwa dampak dari pelaksanaan program BPNT dalam penanggulangan kemiskinan di Kecamatan Nanggalo Kota Padang belum optimal. Hal ini dikarenakan tujuan kebijakan BPNT belum tercapai.

Kata Kunci: evaluasi kebijakan, Bantuan Pangan Non Tunai, penanggulangan kemiskinan ABSTRACT

This study aims to analyze the evaluation of the Non-Cash Food Assistance Program for Poverty Alleviation in Nanggalo Regency, Padang City. Non-Cash Food Assistance (BPNT) is a form of Non-Cash Social Assistance (BSNT) program. The objectives of BPNT according to the Regulation of the Minister of Social Affairs of the Republic of Indonesia Number 20 of 2019, there are: reducing the burden on KPM BPNT expenditure by fulfilling a portion of the food needs; provide balanced nutritious food to KPM BPNT; providing food with the right target, on time, right quantity, right quality, right price, and right administration; and provide more choice and control to KPM BPNT in meeting food needs. This research is a qualitative research with descriptive methods. The research informants were determined by purposive sampling. Data collection techniques are carried out through interviews, observation, and documentation studies and data reduction is carried out so that accurate conclusions can be drawn from the data that has been obtained. The results showed 
8 | evaluasi program bantuan..

that the impact of the implementation of the BPNT program on poverty reduction in Nanggalo Regency, Padang City was not optimal. This is because the objectives of the BPNT policy have not been achieved.

Keywords: policy evaluation, Non-Cash Food Aid, poverty alleviation

\section{PENDAHULUAN}

Kebijakan

peningkatan kesejahteraan masyarakat telah lama menjadi permasalahan di berbagai daerah di Indonesia. Hal ini, karena masih banyak masyarakat miskin yang belum memperoleh manfaat dari program pemerintah terutama dalam meningkatkan kesejahteraan hidup masyarakat. Undang-Undang Nomor 11 Tahun 2009 tentang Kesejahteraan Sosial mendefinisikan kesejahteraan sosial sebagai suatu kondisi terpenuhinya kebutuhan material, spiritual, dan sosial warga negara agar dapat hidup layak dan mampu mengembangkan diri, sehingga dapat melaksanakan fungsi sosialnya. Salah satu kebutuhan material yang mendasar bagi manusia adalah pangan.

Pangan merupakan satu unsur dalam konsep kesejahteraan sosial (Suradi, 2015, 1-12) dalam (Abidin, 2015:215). Menurut Undang-Undang Nomor 18 tahun 2012 tentang Pangan mendefinisikan pangan merupakan kebutuhan dasar yang paling utama dan mempengaruhi kehidupan setiap manusia. Pemerintah telah memberikan subsidi Pangan/Rastra mulai sejak 1997 dalam bentuk Operasi Pasar Khusus (OPK) di antaranya untuk merespon adanya krisis ekonomi dan kemarau yang berkepanjangan. Pada 2002 program
OPK tersebut berubah menjadi Subsidi Raskin (beras miskin) dengan jumlah beras yang diterima yaitu 15 $\mathrm{Kg} / \mathrm{KPM} /$ Bulan dengan biaya tebus Rp1.600/Kg. Pada tahun 2013, Kementerian Sosial (Kemensos) mendapat penugasan sebagai Kuasa Pengguna Anggaran (KPA) Subsidi Pangan/Raskin, dan pada 2016 istilah Raskin diubah menjadi Rastra atau Beras Untuk Keluarga Sejahtera yang diberikan kepada 15,6 juta keluarga. Sebagaimana arahan Presiden agar bantuan sosial disalurkan secara nontunai, maka pada tahun 2017 mulai dilaksanakan transformasi Rastra dari subsidi beras ke bantuan sosial dalam bentuk Bantuan Pangan Non Tunai (BPNT) (Saptawati, 2019).

Dalam rangka meningkatkan efektivitas dan ketepatsasaran penyaluran bantuan sosial serta untuk mendorong keuangan inklusif maka Presiden Republik Indonesia (RI) pada Ratas tentang Keuangan Inklusif tanggal 26 April 2016 memberikan arahan agar bantuan sosial dan subsidi disalurkan secara non tunai (Pedoman Pelaksanaan BPNT, 2017). Maka dari itu Presiden menetapkan Perpres RI Nomor 63 Tahun 2017 tentang Penyaluran Bantuan Sosial Secara Non Tunai sebagai landasan hukum sekaligus pedoman umum untuk pelaksanaan program bantuan 
Journal of Civic Education (ISSN: 2622-237X)

Volume 4 No. 12021

sosial secara non tunai. Dalam Peraturan tersebut dijelaskan bahwa pertimbangan penyaluran bantuan sosial secara non tunai adalah untuk alasan efisiensi, tepat sasaran, tepat jumlah, tepat waktu, tepat kualitas, tepat administrasi, peningkatan manfaat bagi penerima bantuan serta dapat berkontribusi terhadap keuangan inklusif. Bantuan sosial non tunai dengan menggunakan sistem perbankan dapat mendukung perilaku produktif penerima bantuan serta meningkatkan transparansi dan akuntabilitas program bagi kemudahan mengontrol, memantau, dan mengurangi penyimpangan.

Salah satu bentuk program Bantuan Sosial Non Tunai adalah Bantuan Pangan Non tunai (BPNT). Pelaksanaan BPNT mengacu pada Peraturan Menteri Sosial Republik Indonesia Nomor 20 Tahun 2019 tentang Penyaluran BPNT. BPNT adalah bantuan sosial pangan dalam bentuk non tunai dari pemerintah yang diberikan kepada KPM setiap bulannya melalui mekanisme akun elektronik yang digunakan hanya untuk membeli bahan pangan di pedagang bahan pangan/e-warong yang bekerjasama dengan bank. Ewarong adalah istilah yang digunakan dalam BPNT untuk menyebutkan agen bank, pedagang dan/atau pihak lain yang telah bekerja sama dengan bank penyalur dan ditentukan sebagai tempat pembelian bahan pangan oleh KPM, yaitu pasar tradisional, warung, toko kelontong, e-Warong KUBE, Warung Desa, Rumah Pangan Kita (RPK), Agen Laku Pandai, Agen Layanan Keuangan Digital (LKD) yang menjual bahan pangan, atau usaha eceran lainnya (Pedoman
Umum Bantuan Pangan Non Tunai, 2018).

Besaran Bantuan Pangan Non Tunai adalah Rp.110.000,/KPM/bulan yang ditransfer melalui Kartu Keluarga Sejahtera. Bantuan tersebut tidak dapat diambil tunai, dan hanya dapat ditukarkan dengan beras dan/atau telur di e-warong. Apabila bantuan tidak dibelanjakan di bulan tersebut, maka nilai bantuan tetap tersimpan dan terakumulasi dalam Akun Elektronik Bantuan Pangan (Pedoman Pelaksanaan Bantuan Pangan Non Tunai. 2017 : 45). Alat Pembayaran Elektronik Bantuan Pangan Non Tunai yang selanjutnya disebut Kartu Kombo merupakan instrumen pembayaran yang memiliki fitur uang elektronik dan tabungan yang dapat digunakan sebagai media penyaluran berbagai Bantuan Sosial, termasuk Kartu Keluarga Sejahtera. Bank Penyalur BPNT yang selanjutnya disebut Bank Penyalur adalah bank mitra kerja Pemerintah yang menyalurkan dana bantuan pangan kepada Keluarga Penerima Manfaat (KPM) secara non tunai. Adapun tujuan Program Bantuan Pangan Non Tunai menurut Permensos Nomor 20 tahun 2019 adalah sebagai berikut: 1) mengurangi beban pengeluaran KPM BPNT melalui pemenuhan sebagian kebutuhan pangan; 2) memberikan bahan pangan dengan gizi seimbang kepada KPM BPNT; 3) memberikan bahan pangan dengan tepat sasaran, tepat waktu, tepat jumlah, tepat kualitas, tepat harga, dan tepat administrasi; dan 4) memberikan lebih banyak pilihan dan kendali kepada KPM BPNT dalam memenuhi kebutuhan pangan. 
Program BPNT mulai dilaksanakan di Kota Padang pada tahun 2017, dimana kota Padang merupakan salah satu Pilot Project dari 44 kota terpilih di Indonesia. Pelaksanaan BPNT di Kota Padang selama ini belum optimal dilakukan. Untuk kecamatan Nanggalo misalnya, pada tahun 2018 daerah tersebut memiliki jumlah Rumah tangga Miskin sebanyak 1.505. Sedangkan jumlah kuota BPNT yang didapatkan oleh kecamatan tersebut hanya sebanyak 1.315. Artinya, ada sekitar 190 RTM yang tidak menerima bantuan. Untuk tahun 2020 jumlah Data Terpadu Kesejahteraan Sosial (DTKS) Kecamatan Nanggalo sebanyak 3.648 Keluarga, sedangkan yang baru terdaftar sebagai penerima manfaat sebanyak 1.268 KPM.

Artinya ada sekitar 1.824 KPM

yang seharusnya juga berhak mendapatkan bantuan BPNT. Permasalahan lainnya yang terjadi di Kecamatan Nanggalo selama penyaluran BPNT tahun 2018 adalah terdapat 24 kasus kartu KKS yang bermasalah (kartu hilang,kartu rusak,kartu terblokir, belum dapat kartu dari awal). Angka kasus ini adalah yang paling tinggi dibandingkan dengan 10 kecamatan lainnya di Kota Padang. Dan terdapat 1 kasus saldo kosong pada tahun 2018 : (Laporan Kunjungan Kerja Spesifik Komisi VIII DPR tahun 2019).

Dari temuan diatas terlihat bahwa pelaksanaan BPNT di Kota Padang khususnya di kecamatan Nanggalo belum optimal. Hal ini, disebabkan karena: Pertama, upaya untuk mengurangi beban pengeluaran KPM melalui pemenuhan sebagian kebutuhan pangan belum optimal dilakukan. Hal ini berdampak kepada kebutuhan Pangan Keluarga Penerima Manfaat (KPM) secara signifikan belum terpenuhi. Permasalahan ini, disebabkan karena indeks jumlah besaran BPNT dinilai belum mampu untuk memenuhi kebutuhan masingmasing KPM selama sebulan. Kedua, belum optimalnya pelaksanaan program BPNT dalam rangka memberikan nutrisi yang lebih seimbang kepada KPM. Ketiga, belum efektifnya penetapan sasaran/target group dari program BPNT. Keempat, adanya permasalahan teknis seperti kasus kartu rusak dan saldo kosong dalam Kartu Keluarga Sejahtera (KKS).

Permasalahan ini juga disebabkan karena adanya ketidak sinkronan data by name by address penerima BPNT antara data dalam aplikasi Sistem Informasi Kesejahteraan Sosial-NextGeneration (SIKS-NG) dengan data yang dimiliki oleh Himpunan Bank Negara (Himbara) sebagai bank penyalur bantuan sehingga susah melakukan verifikasi dan validasi. Akibatnya, keluarga penerima manfaat mengalami kesulitan menukarkan voucher untuk membeli kebutuhan pangan.

\section{METODE PENELITIAN}

Penelitian ini menggunakan pendekatan kualitatif deskriptif. Menurut Bogdan dan Taylor dalam Moleong (2005:4) mendefinisikan penelitian kualitatif sebagai prosedur penelitian yang menghasilkan data deskriptif berupa kata-kata tertulis atau lisan dari orang-orang dan perilaku yang diamati dari fenomena yang terjadi. Lokasi yang menjadi tempat penelitian ini yaitu Kecamatan Nanggalo Kota Padang. Pengambilan 
informan dalam penelitian ini menggunakan teknik purposive sampling. Informan dipilih berdasarkan karakteristik orang-orang yang benar-benar memahami permasalahan yang diteliti.

Adapun informan penelitian ini yaitu Sekretaris Dinas Sosial Kota Padang, Kepala Bidang Penanganan Fakir Miskin Dinas Sosial Kota Padang, Kepala Seksi Kesejahteraan Sosial dan Tenaga Kesejahteraan Sosial Kecamatan Nanggalo, Pendamping PKH Kelurahan dan Pendamping Sosial Masyarakat Kelurahan Surau Gadang dan Keluarga Penerima Manfaat di Kelurahan Surau Gadang dan KPM di Kelurahan Kurao Pagang Kecamatan Nanggalo. Teknik pengumpulan data dilakukan melalui wawancara, observasi, dan studi dokumentasi. Uji keabsahan data penulis menggunakan teknik triangulasi dan menggunakan bahan referensi. Selanjutnya, data yang diperoleh akan dianalisis melalui tahap reduksi data, penyajian data dan penarikan kesimpulan. HASIL DAN PEMBAHASAN Pelaksanaan Bantuan Pangan Non Tunai dalam Penanggulangan Kemiskinan di Kecamatan Nanggalo Pelaksanaan BPNT mengacu pada Peraturan Menteri Sosial Republik Indonesia Nomor 20 Tahun 2019 Tentang Penyaluran Bantuan Pangan Non Tunai. Program BPNT mulai dilaksanakan di Kota Padang pada tahun 2017, dimana kota Padang merupakan salah satu Pilot Project dari 44 kota terpilih di Indonesia. Pelaksanaan program BPNT diberikan dalam rangka: Pertama, untuk mengurangi beban pengeluaran KPM melalui pemenuhan sebagian kebutuhan pangan. Berdasarkan temuan di lapangan, peneliti menilai pelaksanaan program BPNT di Kecamatan Nanggalo sudah dapat mengurangi beban pengeluaran KPM melalui pemenuhan sebagian kebutuhan pangan KPM. Hal ini dibuktikan dari hasil wawancara peneliti bersama beberapa KPM, umumnya mereka mengungkapkan bahwa mereka merasa sangat terbantu dengan adanya Bantuan ini, karena dapat meringankan beban pengeluaran mereka.

Temuan ini sesuai dengan pendapat Suharto (2012:62) tentang tujuan dari kebijakan sosial dalam rangka pemenuhan kebutuhan keluarga, dimana dalam program ini diberikan melalui pemenuhan sebagian kebutuhan pangan. Menurut Suharto (2012:62) bahwa salah satu tujuan kebijakan sosial adalah untuk memenuhi kebutuhan-kebutuhan individu, keluarga, kelompok atau masyarakat yang tidak dapat mereka penuhi secara sendiri-sendiri melainkan harus melalui tindakan kolektif.

Kedua, pelaksanaan program BPNT diberikan dalam rangka untuk memberikan nutrisi yang lebih seimbang kepada KPM. Berdasarkan ketentuan yang tertulis pada Pedoman Umum BPNT tahun 2018, jenis komoditi pangan yang boleh ditukarkan oleh KPM di ewarong/agen BRI-Link, adalah beras dan telur saja. Kemudian setelah program BPNT bertransformasi menjadi program sembako pada awal tahun 2020, terdapat perluasan jenis komoditas pangan lainnya yang 
mengandung sumber karbohidrat, protein hewani, protein nabati maupun vitamin dan mineral sebagai upaya dari Pemerintah untuk memberikan akses Keluarga Penerima Manfaat terhadap bahan pokok dengan kandungan gizi lainnya. Pengembangan jenis bahan pangan yang didapatkan dari program ini akan mampu meningkatkan nutrisi/gizi masyarakat, terutama anak-anak sejak dini sehingga akan memiliki pengaruh terhadap penurunan stunting.

Namun fakta di lapangan banyak ditemukan KPM tidak membelanjakan kebutuhan sesuai dengan ketentuan yang tertulis dalam pedoman umum program BPNT. Umumnya KPM membelanjakan bantuan tersebut dalam bentuk kebutuhan lain seperti minyak dan gula. Padahal minyak dan gula bukan termasuk ke dalam jenis komoditas pangan yang tertulis dalam ketentuan. Selain itu, jika merujuk pada ketentuan pedoman umum terbaru (Pedum Program Sembako 2020) juga dijelaskan bahwasannya minyak dan gula merupakan jenis bahan pangan yang tidak diperbolehkan dibeli dengan dana bantuan BPNT. Apabila KPM membeli jenis komoditas diluar dari jenis komoditas yang ditentukan maka tujuan BPNT untuk memberikan gizi yang seimbang kepada KPM tidak akan tercapai.

Ketiga, pelaksanaan program BPNT diberikan dalam rangka meningkatkan ketepatan sasaran dan waktu penerimaan Bantuan Pangan bagi KPM. Berdasarkan temuan di lapangan, umumnya implementor dan KPM menilai bahwa program BPNT ini belum sepenuhnya tepat sasaran. Karena masih banyak masyarakat dengan status prasejahtera yang belum mendapatkan manfaat dari program ini. Untuk tahun 2020, jumlah DTKS Kecamatan Nanggalo sebanyak 3.648 RTM, sedangkan yang baru menerima bantuan ini sebanyak 1.268 KPM.

Artinya ada sekitar $1.824 \mathrm{KPM}$ yang seharusnya juga berhak mendapatkan bantuan BPNT di Kecamatan Nanggalo. Indiahono (2009:143) menyatakan bahwa implementasi kebijakan adalah tahap menentukan apakah kebijakan yang ditempuh oleh pemerintah benarbenar aplikabel di lapangan dan berhasil untuk menghasilkan output dan outcomes seperti yang telah direncanakan. Apabila pendapat Indiahono diatas dikaitkan dengan temuan dilapangan maka dapat peneliti nilai bahwasannya program BPNT belum bisa menghasilkan output dan outcomes seperti yang direncanakan, karena penetapan sasaran kebijakan dari program ini belum sepenuhnya optimal, sehingga hasil yang ingin dicapai belum maksimal.

Keempat, pelaksanaan program BPNT diberikan dalam rangka memberikan lebih banyak pilihan dan kendali kepada KPM dalam memenuhi kebutuhan pangan. Walaupun KPM telah diberikan banyak pilihan untuk membeli jenis komoditas pangan, namun KPM harus tetap patuh pada ketentuan yang untuk tidak membeli jenis bahan pangan diluar ketentuan yang sudah tertulis. Namun, fakta dilapangan mengungkapkan bahwa masih banyak KPM yang membelanjakan dana bantuan dengan jenis komoditas diluar ketentuan seperti membeli minyak goreng, gula dan bahan 
pokok pabrikan lainnya diluar dari ketentuan komoditas yang ditentukan. Padahal dalam pedoman umum terbaru program BPNT/program Sembako sudah dijelaskan bahwasanya bantuan BPNT/Program Sembako tidak boleh digunakan untuk pembelian: minyak, tepung terigu, gula pasir, MP-ASI pabrikan, makanan kaleng, mie instan dan bahan pangan lainnya yang tidak termasuk dalam ketentuan.

Bantuan juga tidak boleh digunakan untuk pembelian pulsa dan rokok. Fenomena ini juga disebabkan karena agen E-Warong umumnya sudah memaketkan bahan pangan, yaitu menjual bahan pangan dengan jenis dan dalam jumlah yang ditentukan sepihak oleh e-warong. Padahal dalam ketentuan terbaru dari program bantuan sosial pangan, ewarong tidak boleh memaketkan bahan pangan, yaitu menjual bahan pangan dengan jenis dan dalam jumlah yang ditentukan sepihak oleh e-warong atau pihak lain sehingga KPM tidak mempunyai pilihan.

Keberhasilan implementasi Program BPNT ini perlu didukung oleh optimalisasi komunikasi pelaksanaan program. Hal ini, karena komunikasi yang intensif dalam menyampaiakan manfaat dan tujuan program, dapat meningkatkan dukungan masyarakat terhadap program (Fitri, S. \& Yusran, R, 2020).

Dampak Pelaksanaan Program BNPT terhadap Penanggulangan Kemiskinan di Nanggalo

Istilah 'evaluasi' dalam bahasa sering digunakan untuk melihat sejauh mana program-program kebijakan meraih dampak yang diinginkan. Lester dan Stewart membedakan evaluasi kebijakan ke dalam dua tugas yang berbeda. Pertama, menentukan konsekuensikonsekuensi apa yang ditimbulkan oleh suatu kebijakan dengan cara menggambarkan dampaknya. Kedua, untuk menilai keberhasilan atau kegagalan dari suatu kebijakan berdasarkan standar atau kriteria yang telah ditetapkan sebelumnya. Dengan demikian, melakukan evaluasi kebijakan BPNT berarti melihat apakah ada dampak yang signifikan dalam penanggulangan kemiskinan di Kota Padang (R. Yusran, 2007).

Berkaitan dengan standar dan kriterian evalaluasi kebijakan Dunn (1999) menjelaskan evaluasi kebijakan berkenaan dengan kinerja dari kebijakan khususnya pada implementasi kebijakan publik. Menurut Dunn (1999) evaluasi kebijakan dapat dilakukan dengan menggunakan criteria efektivitas, efisiensi, kecukupan, responsivitas dan ketepatan.

\section{a) Efektivitas}

Menurut Dunn dalam Mulyadi (2016: 124) fokus dari kriteria efektivitas ini terletak pada pencapaian hasil/tujuan. Agar pelaksanaan program bantuan sosial mencapai tujuan yang optimal, maka tujuan utama program harus tercapai sesuai dengan penetapan target group/sasaran dari program kebijakan tersebut. Untuk itu, diperlukan sumber informasi dan data yang akurat guna membantu mengurangi kesalahan dalam penetapan sasaran penerima program BPNT. Berdasarkan kriteria evaluasi ini, capaian tujuan program yang sudah ditetapkan belum optimal yang terlihat dari keterbatasan 
ketercakupan Program BPNT bagi KPM.

Fenomena ini disebabkan karena, masih terjadinya inclusion dan exclusion error. Inclusion error adalah error yang terjadi karena orang yang tidak berhak menerima manfaat tapi masuk database sebagai penerima manfaat. Sedangkan exclusion error adalah error yang terjadi karena orang yang berhak menerima manfaat tidak masuk di database sebagai penerima manfaat. Permasalahan ini berdampak kepada upaya pencegahan kemiskinan di Kota Padang.

b) Efisiensi

Menurut Dunn dalam Mulyadi (2016: 124) menjelaskan efisiensi berkaitan dengan jumlah usaha yang diperlukan untuk menghasilkan tingkat efektivitas tertentu. Adapun usaha yang dilakukan oleh implementor agar pelaksanaan program BPNT Nanggalo ini tepat sasaran yaitu dengan melakukan verivali (verifikasi dan validasi). Calon kelompok penerima manfaat BPNT diambil dari DTKS (Data Terpadu Kesejahteraan Sosial). DTKS merupakan sumber data dari pusat untuk penetapan sasaran programprogram perlindungan sosial. Sumber utama data DTKS merupakan data hasil pendataan BPS tahun 2011 yang dimutakhirkan pada tahun 2015. Karena sumber data yang digunakan merupakan data lama, sehingga mengharuskan petugas kelurahan, Pendamping Sosial Masyarakat (PSM) dan TKSK (Tenaga Kesejahteraan Sosial Kecamatan) untuk melakukan verifikasi dan validasi terlebih dahulu untuk mencek kondisi sosial ekonomi terkini dari calon penerima manfaat.

Demi mendukung suatu program kebijakan mencapai kinerja tertingginya, maka diperlukan upaya atau aksi nyata dari para implementor agar program tersebut berjalan efektif. Kegiatan verifikasi dan validasi yang dilakukan oleh Petugas Sosial Masyarakat \& Tenaga Kesejahteraan Sosial Kecamatan merupakan salah satu bentuk upaya yang dilakukan oleh implementor agar program BPNT ini diberikan pada sasaran yang tepat. Namun meskipun kegiatan verifikasi dan validasi telah dilakukanoleh petugas, namun masih ada masyarakat pra-sejahtera di Kecamatan Nanggalo yang luput dari pendataan, sehingga terjadilah exclusion error (error yang terjadi karena orang yang berhak menerima manfaat tidak masuk di database sebagai penerima manfaat).

\section{c) Kecukupan}

Dunn dalam Mulyadi (2016: 124) menjelaskan kriteria kecukupan berkaitan dengan seberapa jauh suatu tingkat efektivitas memuaskan kebutuhan. Berdasarkan temuan di lapangan, Keluarga Penerima Manfaat (KPM) dan implementor menilai bahwa besaran manfaat yang diberikan setiap bulannya belum bisa mencukupi kebutuhan pangan KPM selama satu bulan. Sebab, besaran jumlah bantuan dari BPNT ini tidak disesuaikan dengan jumlah anggota keluarga. Estimasi makan perhari dari setiap KPM tentu berbeda-beda, tergantung jumlah anggota keluarganya, sedangkan besaran jumlah bantuan yang diterima semuanya sama rata yaitu senilai Rp.110.000 (pada program BPNT) dan Rp.150.000/bulan/KPM (pada program BPNT transformasi). Bagi KPM dengan jumlah anggota keluarga sedikit, jumlah bantuan yang diberikan tersebut tentunya cukup 
karena intensitas konsumsi makanannya tidak terlalu banyak. Sedangkan bagi KPM dengan jumlah anggota keluarga yang banyak tidak akan merasa tercukupi dengan nilai bantuan tersebut.

Berdasarkan observasi yang peneliti lakukan di lapangan, bahan pangan yang dibeli dengan nominal Rp. 110.000 s.d Rp.150.000 untuk KPM dengan jumlah anggota keluarga 4-6 orang, hanya mampu bertahan selama 7-10 hari untuk beras, sedangkan untuk telur hanya bisa bertahan satu minggu. Artinya jumlah besaran yang diberikan program BPNT ini belum bisa mencukupi kebutuhan dari setiap KPM. Apabila besaran bantuan yang diberikan belum dirasa cukup untuk memenuhi kebutuhan pangan KPM, maka bisa dikatakan upaya pemerintah dalam penyelenggaraan kesejahteraan sosial belum optimal.

Menurut UU Nomor 11 Tahun 2009 tentang Kesejahteraan Sosial mendefinisikan kesejahteraan sosial sebagai suatu kondisi terpenuhinya kebutuhan material, spiritual, dan sosial warga Negara agar dapat hidup layak dan mampu mengembangkan diri, sehingga dapat melaksanakan fungsi sosialnya. Salah satu kebutuhan material yang mendasar bagi manusia adalah pangan. Oleh karena itu, pangan merupakan satu unsur dalam konsep kesejahteraan sosial (Suradi, 2015, 1-12) dalam (Abidin, 2015:215). Kecukupan pangan sesuai kebutuhan setiap orang akan menentukan tingkat kesejahteraan suatu masyarakat.

\section{d) Responsivitas}

Dunn dalam Mulyadi (2016: 124) menjelaskan, responsivitas berkaitan dengan seberapa jauh suatu kebijakan dapat memuaskan kebutuhan, preferensi atau nilai masyarakat. Dalam pelaksanaan BPNT di Kecamatan Nanggalo, pada dasarnya KPM merespon dengan baik keberadaan bantuan ini. Dengan adanya BPNT bisa mengurangi beban pengeluaran KPM, walaupun dari segi jumlah bantuan yang diberikan pada program BPNT belum bisa mencukupi dan memuaskan kebutuhan masing-masing KPM perbulannya.

Selanjutnya, dari segi pemilihan jenis komoditas pangan yang telah ditentukan, implementor di kecamatan/kelurahan serta KPM merespon bahwasannya pembatasan jenis komoditas tersebut kurang efektif, karena kebutuhan KPM akan bahan pangan itu berbeda-beda. Berdasarkan hasil wawancara bersama implementor maupun dengan KPM, umumnya mereka berpendapat bahwasannya selama ini jenis komoditas pangan yang dibelanjakan oleh KPM ke agen/ewarong tidak selalu sesuai dengan ketentuan, biasanya mereka membeli bahan pangan yang sesuai dengan yang mereka butuhkan. Jadi tidak melulu beras dan telur yang sudah tertulis pada pedoman umum, tetapi juga dalam bentuk kebutuhan pangan lainnya.

\section{e) Ketepatan}

Kriteria ketepatan menurut Dunn, cenderung menganalisis mengenai manfaat dari suatu kebijakan terhadap kelompok sasaran. Berdasarkan temuan di lapangan, pelaksanaan program BPNT di Kecamatan Nanggalo cukup banyak mendatangkan manfaat bagi KPM. Salah satunya dapat mengurangi beban pengeluaran KPM melalui pemenuhan sebagian kebutuhan 
pangan. Selain itu, Tenaga Kesejahteraan Sosial Nanggalo menyatakan bahwasannya program BPNT mampu untuk meningkatkan kualitas hidup masyarakat prasejahtera disana. Hal ini dibuktikan dengan adanya pengurangan jumlah penerima manfaat BPNT setiap tahunnya dikarenakan beberapa KPM dinilai sudah cukup mampu dan sejahtera sehingga sudah bisa dikeluarkan dari daftar penerima manfaat BPNT.

Berdasarkan temuan dilapangan diatas dapat dilihat bahwasannya program BNPT berkontribusi dalam menekan angka kemiskinan dari sisi pemenuhan kebutuhan dasar masyarakat akan bahan pangan. Berdasarkan data BPS, Garis Kemiskinan Makanan (GKM) memiliki kontribusi besar terhadap pembentukan Garis Kemiskinan (GK). Selain itu, stabilitas harga sembako mempengaruhi penurunan angka kemiskinan. Adanya program BPNT/Sembako akan mengurangi beban pengeluaran keluarga miskin dalam hal makanan, sehingga dapat memastikan sebagian kebutuhan dasar masyarakat miskin terpenuhi.

Di sisi lain, pengembangan jenis bahan pangan yang didapatkan dari program ini akan mampu meningkatkan nutrisi/gizi masyarakat, terutama anak-anak sejak dini sehingga akan memiliki pengaruh terhadap penurunan stunting. Di provinsi Sumatera Barat, per September 2019 terjadi penurunan angka penduduk miskin sebesar 5,13 ribu orang dibandingkan Maret 2019. Menurut Kepala BPS Sumbar Pitono, tren penurunan angka kemiskinan di Sumbar juga ditopang adanya bantuan yang telah digulirkan oleh pemerintah, salah satunya ialah BPNT (Yusfita, 2019).

\section{KESIMPULAN}

Berdasarkan hasil penelitian yang dilakukan oleh peneliti mengenai Evaluasi Program Bantuan Pangan Non Tunai dalam Penanggulangan Kemiskinan di Kecamatan Nanggalo Kota Padang, dapat disimpulkan bahwa pelaksanaan program BPNT di Kecamatan Nanggalo ditinjau dari aspek pencapaian tujuan program belum optimal karena masih terjadinya permasalahan terkait mekanisme pendataan, mekanisme penyaluran dan mekanisme pemanfaatan dana bantuan. Berdasarkan evaluasi yang peneliti lakukan terkait pelaksanaan Program BPNT di Kecamatan Nanggalo, maka dapat disimpulkan bahwa dalam pelaksanaan program BPNT ini masih belum optimal dikarenakan tujuan dari program BPNT belum tercapai. Sedangkan dampak pelaksanaan program BPNT di Kecamatan Nanggalo dinilai cukup mampu untuk meningkatkan kualitas hidup masyarakat pra-sejahtera.

\section{DAFTAR PUSTAKA}

Abidin, M. Zainul. 2015. Dampak Kebijakan Impor Beras Dan Ketahanan Pangan Dalam Perspektif Kesejahteraan Sosial. Sosio Informa Vol. 1, No. 03, September - Desember, Tahun 2015.

Aprina, Y., \& Yusran, R. (2020). Implementasi Peraturan Daerah Kota Bukittinggi Nomor 2Tahun 2015 TentangPencegahan dan Penang-gulangan Bahaya Kebakaran. Jurnal Mahasiswa Ilmu Administrasi Publik, 1(4), 87-97. Retrieved from http://jmiap.ppj.unp.ac.id/inde x.php/jmiap/article/view/49 
Dunn, William N. 1999. Analisis Kebijakan Publik. Yogyakarta: Gadjah Mada University Press.

Fitri, S., \& Yusran, R. (2020). Implementasi Kebijakan Rehabilitasi Pengguna Narkoba pada Badan Narkotika Nasional Provinsi Sumatera Barat. Journal of Civic Education, 3 (3),231-242. https://doi.org/10.24036/jce.v3i $\underline{3.400}$

Indiahono, Dwiyanto. 2009. Kebijakan Publik Berbasis Dynamic Policy Analisys. Yogyakarta: Gava Media.

Moleong, J. Lexy. 2013. Metode Penelitian Kualitatif. Bandung: PT Rosdakarya.

Mulyadi, Deddy. 2016. Studi Kebijakan Publik dan Pelayanan Publik.Bandung : ALFABETA.

Suharto, Edi. 2012. Analisis Kebijakan Publik (Panduan Praktis Mengkaji Masalah dan Kebijakan Sosial). Bandung: ALFABETA

Handika V., Yusran R. (2020). Implementasi Program Kotaku dalam Upaya Mengatasi Pemukiman Kumuh di Kabupaten Lima Puluh Kota. Journal of Civic Education. Volume 3 No. 32020

Retrieved from http://jce.ppj.unp.ac.id/index.p hp/jce/article/view/397

Winarno, Budi. 2002. 2012. 2014. Kebijakan Publik Teori dan Proses. Media Pressindo. Yogyakarta.

Yusran R. 2007. Evaluasi Dampak Kebijakan Pemekaran Daerah di Indonesia: Studi Daerah Pemekaran
Kabupaten Solok Selatan. Jurnal Demokrasi. Vol. 6 No. 2

Retrieved

from

http:/ / ejournal.unp.ac.id/index. $\mathrm{php} / \mathrm{jd} /$ article/view/1138

Mensos :Transformasi Bantuan Pangan Non Tunai Berjalan Sangat Baik, http://rri.co.id diakses tanggal 13 November 2019.

Komisi VIII Temukan Permasalahan Implementasi BPNT, dpr.go.id diakses tanggal 21 Oktober2019

Jumlah Penduduk Miskin di Sumbar Mencapai 343 ribu Jiwa, BPS Sebut Berkurang Dibanding Maret 2019, https://padang.tribunnews.com diakses tanggal 6 Februari 2020.

Pedoman Umum Bantuan Pangan Non Tunai, 2018

Pedomena Pelaksanaan Bantuan Pangan Non Tunai. 2017.

Pedoman Umum Program Sembako 2020

Perpres No 63 tahun 2017 tentang Penyaluran Bantuan Sosial Secara Non Tunai.

Peraturan Menteri Sosial Republik Indonesia Nomor 11 Tahun 2018 Tentang Penyaluran BPNT. Bantuan Pangan Non Tunai (BPNT)

Undang Undang Nomor 18 tahun 2012 tentang Pangan.

Undang Undang Nomor 11 tahun 2009 tentang Kesejahteraan Sosial 